\title{
Short- and Long-Term Biochar Cadmium and Lead Immobilization Mechanisms
}

\author{
Liqiang Cui ${ }^{1}$, Lianqing $\mathrm{Li}^{2, *}$, Rongjun Bian ${ }^{2}$, Jinlong Yan ${ }^{1, *} \mathbb{C}$, Guixiang Quan ${ }^{1}$, Yuming Liu ${ }^{3}$, \\ James A. Ippolito ${ }^{4}$ and Hui Wang ${ }^{1}$ \\ 1 School of Environmental Science and Engineering, Yancheng Institute of Technology, No. 211 Jianjun Road, \\ Yancheng 224003, China; lqcui8@hotmail.com (L.C.); qgx@ycit.cn (G.Q.); whsl@ycit.cn (H.W.) \\ 2 Institute of Resources, Ecosystem and Environment of Agriculture, Nanjing Agricultural University, \\ 1 Weigang, Nanjing 210095, China; brjun@njau.edu.cn \\ 3 Tinghu Station of Agricultural Environment Monitoring, No. 59 Xiwang road, Yancheng 224003, China; \\ liuyuming102986@126.com \\ 4 Department of Soil and Crop Sciences, Colorado State University, Fort Collins, CO 80523, USA; \\ Jim.Ippolito@ColoState.edu \\ * Correspondence: lqli@njau.edu.cn (L.L.); yjlt@ycit.cn (J.Y.)
}

Received: 10 June 2020; Accepted: 12 July 2020; Published: 16 July 2020

\begin{abstract}
The mechanisms of soil $\mathrm{Cd}$ and $\mathrm{Pb}$ alterations and distribution following biochar (BC; 0 to $40 \mathrm{t} \mathrm{ha}^{-1}$ ) amendments applied (in either 2009 [long-term] or in 2016 [short-term]) to a contaminated rice paddy soil, and subsequent plant $\mathrm{Cd}$ and $\mathrm{Pb}$ tissue distribution over time was investigated. Water-soluble $\mathrm{Cd}$ and $\mathrm{Pb}$ concentrations decreased by $6.7-76.0 \%$ (short-term) and $10.3-88.1 \%$ (long-term) with biochar application compared to the control. The soil exchangeable metal fractions (i.e., considered more available) decreased, and the residual metal fractions (i.e., considered less available) increased with short- and long-term biochar amendments, the latter likely a function of biochar increasing $\mathrm{pH}$ and forcing $\mathrm{Cd}$ and $\mathrm{Pb}$ to form crystal mineral lattice associations. Biochar application reduced $\mathrm{Cd}(16.1-84.1 \%)$ and $\mathrm{Pb}(4.1-40.0 \%)$ transfer from root to rice grain, with rice $\mathrm{Cd}$ and $\mathrm{Pb}$ concentrations lowered to nearly Chinese national food safety standards. Concomitantly, soil organic matter (SOM), $\mathrm{pH}$ and soil water content increased by $3.9-49.3 \%, 0.05-0.35 \mathrm{pH}$ units, and 3.8-77.4\%, respectively, with increasing biochar application rate. Following biochar applications, soil microbial diversity (Shannon index) also increased (0.8-46.2\%) and soil enzymatic activities were enhanced. Biochar appears to play a pivotal role in forcing $\mathrm{Cd}$ and $\mathrm{Pb}$ sequestration in contaminated paddy soils, reducing heavy metal transfer to rice grain, and potentially leading to reduced heavy metal consumption by humans.
\end{abstract}

Keywords: biochar; cadmium; lead; contaminated paddy soil; short- and long-term mechanisms

\section{Introduction}

Soil heavy metal pollution is a worldwide problem, with accumulation leading to toxicity and environmental persistence; this is especially true for cadmium $(\mathrm{Cd})$ and lead $(\mathrm{Pb})$, both of which pose serious human and ecological health threats [1,2]. In China, over $16 \%$ of all agricultural soils are contaminated with heavy metals, with soil $\mathrm{Cd}$ and $\mathrm{Pb}$ concentrations exceeding China's environmental standards in $7 \%$ and $1.5 \%$ of all arable lands $\left(9.8 \times 10^{4}\right.$ and $2.1 \times 10^{4} \mathrm{~km}^{2}$, respectively [3]. It is obvious that in order to protect human health and the environment, reducing heavy metal bioavailability is of paramount importance.

Reducing heavy metal bioavailability has followed several pathways, including amendment additions for heavy metal stabilization [4]. Heavy metal stabilization is typically dominated by 
chemisorption mechanisms, with other sorption mechanisms such as ion exchange, electrostatic attraction and complexation playing roles [1]. Stabilization/immobilization has been considered practical with respect to short-term effectiveness when using different stabilizers, yet longer-term effectiveness does require more research, especially for the biochar [5]. For example, Senneca et al., found that a cement-based stabilization/solidification treatment positively affected a chromium $(\mathrm{Cr})$ contaminated soil, with the treatment increasing the amount of $\mathrm{Cr}$ in the soil residual fraction and thus reducing its mobility [6]. Cui et al., found that the biochar could stabilize $\mathrm{Cd}$ and $\mathrm{Pb}$ in the paddy soil and reduce the rice uptake in short term [7]. Finding a heavy metal stabilizing material that is effective both in the short- and long-term may be as simple as utilizing biochar [8].

Biochars are created by pyrolyzing various carbonaceous materials, such as agricultural crops wastes, at moderate temperature under anoxic conditions [9]. Biochar is widely accepted as an effective agent for reducing heavy metal bioavailability via biochar organic-heavy metal complexation and biochar oxide, hydroxide, and carbonate phase-heavy metal precipitation [10]. As examples, Khan et al., showed that corn straw biochar could effectively sorb Cd via chemisorption, electrostatic interactions, and inner-sphere complexation reactions [11]. Golden shower tree (Cassia fistula) biochar has been shown to sorb and remove up to $303.5 \mathrm{mg} \mathrm{Cu} \mathrm{g}^{-1}$ from wastewater [12]. In addition, barley grass biochar has been proven to sorb $\sim 90$ to $95 \%$ of soil borne $\mathrm{Cu}$ and $\mathrm{Pb}$ from a contaminated soil, leading to enhanced plant growth [13].

Increasing heavy metal sorption via biochar use can lead to alterations in heavy metal phases present in contaminated soils. Essentially, relatively high bioavailable heavy metal concentrations can be altered to less bioavailable forms via biochar application to metal-contaminated soils. Qin et al., showed that the addition of pig manure biochar to contaminated soil sorbed both $\mathrm{Cd}$ and $\mathrm{Pb}$, reducing their leaching losses (i.e., bioavailable forms) by 38\% and 71\%, respectively, as compared to a control [14]. Ippolito et al., observed up to an $88 \%$ and $100 \%$ decrease in bioavailable $\mathrm{Cd}$ and $\mathrm{Pb}$, respectively, with the use of either lodgepole pine or tamarisk biochar in metal contaminated soils; decreases were driven by precipitation reactions [15]. Cadmium sorption onto wheat straw biochar was driven by precipitation reactions [e.g., $\mathrm{Cd}(\mathrm{OH})_{2}$ and $\mathrm{CdCO}_{3}$ ] and interaction with carbonyl and carboxyl groups, leading to reduced bioavailable soil $\mathrm{Cd}$ concentrations [16]. Water hyacinth biochar has been shown to decrease rice paddy soil exchangeable Cd content by $\sim 25 \%$, while increasing Cd in less-bioavailable forms such as those associated with carbonate- and Fe/Mn oxide phases [17].

Altering heavy metal phases present, in favor of lower bioavailability, has been linked to alterations in plant and human metal uptake. For example, corn straw biochar has been shown to significantly reduce the proportion of $\mathrm{Cd}$ in the soil exchangeable and carbonate phases (i.e., relatively highly bioavailable) and increase the proportion of $\mathrm{Cd}$ in the residual fraction (i.e., highly unavailable), leading to a decrease in plant and human bioavailability [18]. Bian et al., reported that wheat straw biochar reduced $\mathrm{Cd}$ and $\mathrm{Pb}$ bioavailability by $\sim 60 \%$ via sorption onto biochar (hydr)oxide phases present (i.e., unavailable), with $\mathrm{Cd}$ and $\mathrm{Pb}$ rice uptake reduced by between $27 \%$ and $69 \%$, suggesting lower heavy metal consumption by humans [19].

The above studies indicate that biochars may be used to not only sorb, but to alter heavy metals forms to those less bioavailable. However, the additional benefit of biochar land application lies in the fact that biochars can also positively alter soil physicochemical attributes. Zhang et al., showed that rice straw biochar sorbed and immobilized heavy metals, while improving soil water and nutrient dynamics [20]. Bamboo biochar has been shown to increase acidic soil pH, available K, $\mathrm{Fe}, \mathrm{Mg}$, and Mn content, and SOM, while decreasing bioavailable heavy metal mobility via surface adsorption and precipitation reactions [21]. Cui et al., reported that biochar increased soil pH and SOM, and significantly reduced metal bioavailability, leading to a decrease in rice and wheat grain metal concentrations over the short-term (i.e., 2 years) [7,22]. Cui et al., showed a similar long-term (i.e., 5 years) trend with wheat straw biochar-Cd/Pb sorption in an amended paddy soil [23].

Based on the information presented above, continued research is needed to verify biochar alterations to soil properties, heavy metal bioavailability, and plant metal uptake over short- and 
longer-term timeframes. Desperately required is a focus on in-field research. Thus, the objective of the present study was to evaluate the mechanisms by which biochar alters soil physicochemical as well as biological properties, soil $\mathrm{Cd}$ and $\mathrm{Pb}$ bioavailability, and the corresponding metal uptake in rice from a contaminated paddy soil under the short- and long-term. Our hypothesis was that biochar would bind $\mathrm{Cd}$ and $\mathrm{Pb}$ and reduce the soil bioavailable fraction/increase the recalcitrant fraction, leading to less $\mathrm{Cd}$ and $\mathrm{Pb}$ uptake by rice over both a relatively short and longer timeframe. This hypothesis should be supported by correlations between chemical, physical, and biological changes in soil due to biochar application.

\section{Materials and Methods}

\subsection{Site Description}

The experiment was conducted in a paddy field $\left(31^{\circ} 24.434^{\prime} \mathrm{N}\right.$ and $\left.119^{\circ} 41.605^{\prime} \mathrm{E}\right)$, where atmospheric fallout and effluent discharges from a local $\mathrm{Pb}$ smelter have contaminated the site since at least the 1970s. Cadmium and Pb are the primary metal contaminants in this area. The paddy soil was characterized as a Ferric-accumulic Stagnic Anthrosol [24].

\subsection{Experimental Design}

The long- and short-term biochar experiments commencement in May 2009 and May 2016, respectively, within a continuous rice rotation. The long- and short-term plots were adjacent to one another in the field, using the same experimental design for both experiments; within the text below, the short and long-term experiments are designated as "S" and " $\mathrm{L}$ ". Individual $4 \times 5 \mathrm{~m}$ plots were laid out in a randomized complete block design with three replicates per treatment.

Biochar was created from wheat straw via pyrolysis at $\sim 450^{\circ} \mathrm{C}$ at the Sanli New Energy Company, Henan Province, China. Treatments included four biochar application rates of $0(\mathrm{C} 0), 10(\mathrm{C} 1), 20(\mathrm{C} 2)$ and 40 (C3) tha ${ }^{-1}$, which were surface-applied, raked to relative uniformity, and then fully incorporated into the soil to approximately a $15 \mathrm{~cm}$ depth by plowing. Biochar and background soil were collected, returned to the lab, ground to pass a 2-mm sieve, with basic biochar and soil properties determined using methods outlined by $\mathrm{Lu}$ [25]; data are presented in Table S1.

\subsection{Sample Collection and Analysis}

\subsubsection{Donnan Membrane Technique Setup}

The Donnan membrane technique (DMT), which identifies water-soluble $\mathrm{Cd}$ and $\mathrm{Pb}$ throughout the rice growing season, was used in-field for every month from August to November 2016, 2017, and 2018. This in-situ technique utilizes an acceptor cell (i.e., $10 \mathrm{~mL}$ of $0.01 \mathrm{~mol} \mathrm{~L}^{-1} \mathrm{CaCl}_{2}$, with Ca moving out of the cell when heavy metal cations move into the cell), separated by a positively charged membrane (BDH, No. 55165 2U) held by two O-rings [26] (Figure S1). The BDH membrane has a matrix of polystyrene/divinylbenzene, with sulphonic acid groups which are fully deprotonated above $\mathrm{pH}=2$. The solution was changed every month over the study period. Solution $\mathrm{Cd}$ and $\mathrm{Pb}$ concentrations were determined by graphite furnace atomic absorption spectrometry (GFAAS, Zeenit 700p, Jena, Germany).

\subsubsection{The Rice Plant Collection}

During harvest, three whole rice plants were randomly collected from each plot by gently pulling the entire plant out of the ground. The samples were washed with tap water and deionized water to remove soil, and then separated into roots, shoots, and grain. The plant samples were dried at $105^{\circ} \mathrm{C}$ for $30 \mathrm{~min}$ and then at $60^{\circ} \mathrm{C}$ until dry, then crushed with a pulverizer and stored in air-tight polyethylene bags. A $0.50 \mathrm{~g}$ plant sample was placed in a $100 \mathrm{~mL}$ beaker and predigested overnight in a $10 \mathrm{~mL}$ solution of concentrated $\mathrm{HNO}_{3}$ and $\mathrm{HClO}_{4}(4: 1, v: v)$ at room temperature. The following 
day, the beakers were placed on an electric heating plate with the temperature raised from 100 to $200^{\circ} \mathrm{C}$ over $30 \mathrm{~min}$, then the temperature was increased to $250^{\circ} \mathrm{C}$ until the solution changed colorless, at $\sim 2 \mathrm{~mL}$ of solution remaining. The solutions were then removed, cooled, brought to a $25-\mathrm{mL}$ final volume, and filtered through a $0.45-\mu \mathrm{m}$ membrane filter. The $\mathrm{Cd}$ and $\mathrm{Pb}$ concentration in the digestate were determined with GFAAS.

\subsubsection{The Soil Samples Collection}

Three soil cores ( 0 to $15 \mathrm{~cm}$ depth) were collected from each plot following rice harvest in November 2016, 2017 and 2018. Plant debris was removed and the soil separated into two parts: (1) air-dried at room temperature and then ground to pass a 2-mm sieve; (2) stored at $4{ }^{\circ} \mathrm{C}$ for subsequent microbial activity measurements. Soil $\mathrm{pH}$, soil water and soil organic matter (SOM) were analyzed using methods described by $\mathrm{Lu}$ [25]. Briefly, soil $\mathrm{pH}$ was measured using a glass electrode with a soil-to-water ratio of 1:2.5. Soil water content was determined gravimetrically by weight difference before and after at least six hours of oven drying at $105^{\circ} \mathrm{C}$. The SOM was determined using the dichromate oxidation method. A subsample of the air-dried, ground soil was further ground to pass a $0.15-\mathrm{mm}$ sieve and used to determine total $\mathrm{Cd}$ and $\mathrm{Pb}$ concentrations and sequentially extractable heavy metals fractions as described below $[1,7]$.

\subsubsection{The Soil Heavy Metals Fractions Detection}

Soil heavy metals from the 2016, 2017, and 2018 samples were sequentially extracted using the modified four-stage procedure recommended by the European Community Bureau of Reference (BCR), as described by Ure et al. and briefly described here. Exchangeable fraction (B1; includes soluble, exchange site- and carbonate-bound) [27]: $40 \mathrm{~mL}$ of $0.11 \mathrm{M}$ acetic acid was added to $1 \mathrm{~g}$ of soil in a $50 \mathrm{~mL}$ centrifuge tube and shaken for $16 \mathrm{~h}$ at room temperature, followed by centrifugation and liquid decantation. Iron and manganese oxyhydroxides fraction (B2): $40 \mathrm{~mL}$ of a freshly prepared hydroxyl ammonium chloride was added to the residue from the previous step, shaken for $16 \mathrm{~h}$ at room temperature, followed by centrifugation and decantation. Organic fraction (B3): the residue from the previous step was treated twice with $10 \mathrm{~mL}$ of $8.8 \mathrm{M}$ hydrogen peroxide. The digestion was allowed to stand for $1 \mathrm{~h}$ with occasional manual shaking, followed by digestion at $85 \pm 2{ }^{\circ} \mathrm{C}$ until the volume was reduced to $2-3 \mathrm{~mL}$. Samples were allowed to cool, and then $50 \mathrm{~mL}$ of $1.0 \mathrm{M}$ ammonium acetate was added to the mixture and shaken for $16 \mathrm{~h}$ at room temperature, followed by centrifugation and decantation. Residual fraction (B4; represents metals associated with crystalline mineral phases): residue from the previous step was allowed to air-dry and then digested in a $50 \mathrm{~mL}$ digestion tube by first adding $1 \mathrm{~mL}$ of deionized water to make a slurry, followed by an aqua regia addition $(7 \mathrm{~mL}$ $\mathrm{HCl}$ and $2 \mathrm{~mL} \mathrm{HNO}_{3}$ ). The mixtures were allowed to predigest overnight at room temperature and then digested at $105^{\circ} \mathrm{C}$ for $2 \mathrm{~h}$ the next day. Then, the mixtures were brought to a $50 \mathrm{~mL}$ final volume. The final liquids from all four steps were passed through a 0.45 -micron membrane filter prior to $\mathrm{Cd}$ and $\mathrm{Pb}$ analysis via GFAAS (GFAAS, Zeenit 700 p; Analytik Jena AG, Jena, Germany).

\subsubsection{The Soil Enzymatic Activity Detection}

Soil enzymatic activity, microbial community composition, and bacterial abundance were analyzed on all refrigerated soil samples. Soil alkaline phosphatase activity was measured using the disodium phenyl phosphate method [28]. Soil sucrase activity was measured using the 3,5-dinitrosalicylic acid method [1]. Soil urease and dehydrogenase activities were determined using phenol-sodium hypochlorite and triphenyl tetrazolium chloride methods, respectively [29]. Microbial community composition was determined using a Gene Amp PCR-System 9700 (Applied Biosystems, Foster City, CA, USA). Briefly, the total DNA was extracted from $0.5 \mathrm{~g}$ of soil using a FastDNA Spin Kit for Soil and the FastPrep Instrument (MP Biomedicals, Santa Ana, CA, USA). The DNA quality was assessed on 1\% agarose gel, while the quantity of DNA was determined using a Nanodrop-2000 spectrophotometer (Nanodrop Technologies Inc., Wilmington, DE, USA) [30]. Bacterial abundance 
was quantified following the polymerase chain reaction (PCR) method targeting 515F and 907R (V4-V5 region) primer pairs of $16 \mathrm{~S}$ rDNA. For microbial community analysis, PCR tests were conducted for each DNA sample, and pooled and purified using a QIAquick Gel Extraction Kit (Qiagen, Chatsworth, CA, USA). Approximately equimolar amounts of the PCR products of each sample were combined prior to amplicon sequencing using an Illumina Miseq platform at Shanghai Genesky Biotechnologies (Shanghai, China).

\subsection{Statistical Analysis}

All data were expressed as means \pm one standard deviation of the mean. Differences between the treatments were examined using a two-way analysis of variance (ANOVA), with statistical differences considered when $p<0.05$. All statistical analyses were carried out using SPSS, version 20.0 (SPSS Institute, Chicago, IL, USA). Biochar and soil basic properties, plant heavy metals, microbial diversity, heavy metals present in various soil fractions, and soil enzyme activities were analyzed using principle component analysis (PCA, using SPSS), and PCA was also used to determine correlation coefficients (r) between all of these factors.

The Shannon index $(H)$ of the operational taxonomic units (OTU) for soil microbial community diversity was calculated as:

$$
H=\sum_{i=1}^{S_{o b s}} \frac{n_{i}}{N} \ln \frac{n_{i}}{N}
$$

where $S_{o b s}$ was the OTU detection number, $n_{i}$ was the number of the $i$ th OTU, and $N$ was the sum of all sequence numbers. A bioconcentration factor (BCF) was determined as the above-ground $\mathrm{Cd}$ or $\mathrm{Pb}$ concentration/soil $\mathrm{Cd}$ or $\mathrm{Pb}$ concentration. A translocation factor (TF) was determined by the above-ground plant $\mathrm{Cd}$ or $\mathrm{Pb}$ concentration/root $\mathrm{Cd}$ or $\mathrm{Pb}$ concentration.

\section{Results and Discussion}

\subsection{Biochar Effects on $\mathrm{Cd}$ and $\mathrm{Pb}$ in the Soil Water Soluble Phase and Various Pools}

In-situ dissolved soil $\mathrm{Cd}$ and $\mathrm{Pb}$ concentrations may be considered bioavailable [31]. In-field, soluble soil $\mathrm{Cd}$ and $\mathrm{Pb}$ data, collected via the DMT, are presented in Figure S2. More often than not, increasing biochar application rate decreased paddy field soil water-soluble $\mathrm{Cd}$ and $\mathrm{Pb}$ concentrations over both the short- and long-term. Long-term Cd concentrations significantly decreased by $24.5-52.2 \%$ (2016), 32.1-73.2\% (2017) and 37.1-80.8\% (2018), while Pb concentrations decreased by 32.1-88.1\% (2016), 15.7-82.4\% (2017) and 10.3-46.2\% (2018) (Figure S2A,C) with biochar applications compared to the control. Short-term $\mathrm{Cd}$ and $\mathrm{Pb}$ concentration were significantly decreased by $19.8-46.5 \%$ (2016), 14.5-67.4\% (2017), 30.0-76.0\% (2018) and 6.7-63.3\% (2016), 17.6-65.5\% (2017), 14.3-44.6\% (2018) (Figure $\mathrm{S} 2 \mathrm{~B}, \mathrm{D})$, respectively, with biochar applications compared to the control. Greater short- and long-term $\mathrm{Cd}$ and $\mathrm{Pb}$ decreases were associated with greater biochar application rates. When soluble $\mathrm{Cd}$ increases were observed, they may have been related to increases in water soluble organic phases present that chelated Cd, as suggested by Fan et al. [32]. However, similar to most of our findings, Xu et al., also found that water-soluble $\mathrm{Cd}$ and $\mathrm{Pb}$ concentrations decreased by $59 \%$ and $13 \%$ with macadamia nutshell biochar amendment in a lab incubation study [33]. Comparable $\mathrm{Cd}$ and $\mathrm{Pb}$ results were found by Wang et al., when using rice straw biochar in a pot experiment [34].

Results of the BCR sequential extraction on soil $\mathrm{Cd}$ and $\mathrm{Pb}$ fractions are presented in Figure 1. The exchangeable $\mathrm{Cd}$ and $\mathrm{Pb}$ fractions (B1) were approximately $40 \%$ of the total $\mathrm{Cd}$ and $\mathrm{Pb}$ extracted, yet tended to decrease with increasing biochar application rate. When exchangeable $\mathrm{Cd}$ and $\mathrm{Pb}$ content decreased, it appears that increases were associated with the residual fraction (B4), indicating a reduction in $\mathrm{Cd}$ and $\mathrm{Pb}$ bioavailability and lower potential ecological risk associated with biochar amendment, as suggested by others [35]. In support of these findings, Chen et al., showed that biochar reduced $\mathrm{Cd}$ bioavailability by transforming the exchangeable fraction into the residual fraction, 
associating these changes to increases in soil pH [36]. Wang et al. [37] and Liu et al. [38] both observed similar responses when using wheat straw or coconut shell biochar, respectively, to reduce $\mathrm{Cd}$ bioavailability. Sludge-based biochars have also been shown to decrease $\mathrm{Pb}$ and Cd bioavailability from $55.9 \%$ to $4.9 \%$ for $\mathrm{Pb}$, and from $78.2 \%$ to $12.5 \%$ for $\mathrm{Cd}$ [39].
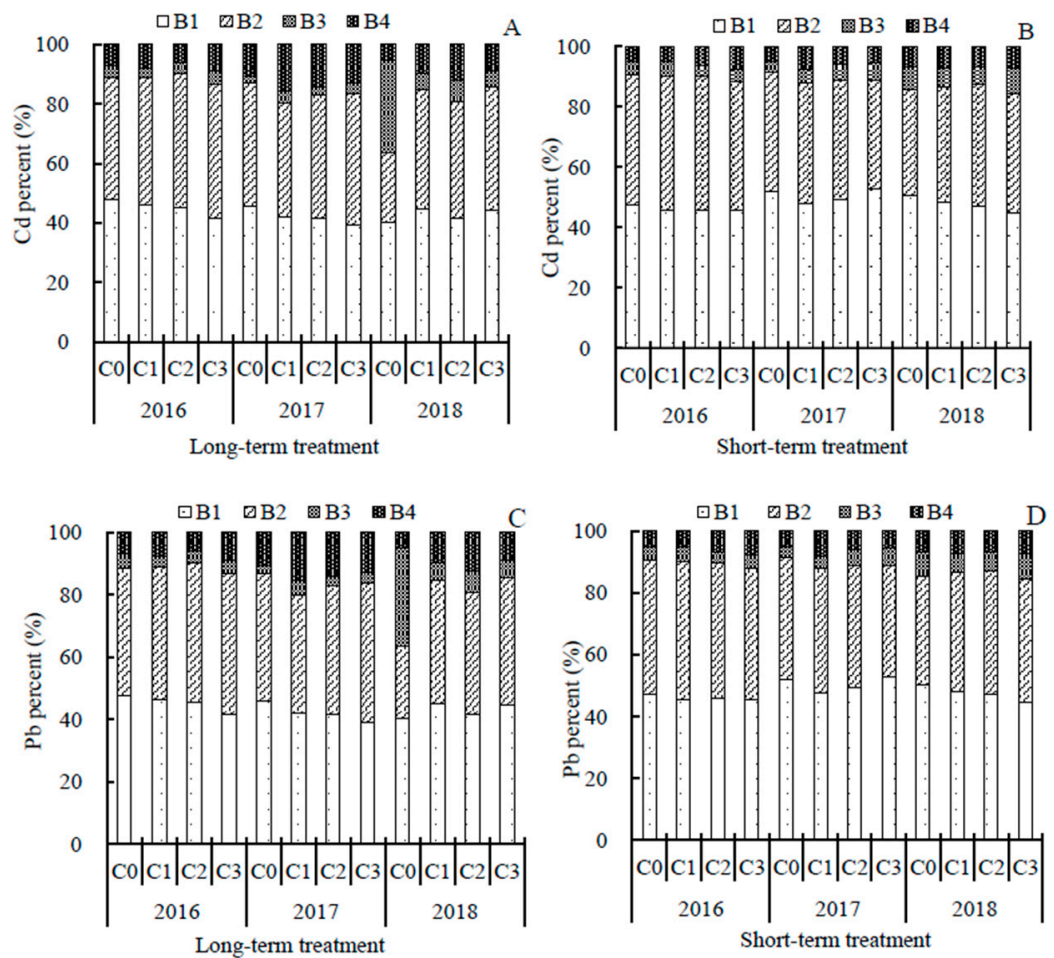

Figure 1. The effect of long- and short-term, increasing biochar application rates [0 (C0), 10 (C1), 20 (C2) and 40 (C3) $\mathrm{t} \mathrm{ha}^{-1}$ ] on $\mathrm{Cd}$ and $\mathrm{Pb}$ fractions based on a European Community Bureau of Reference (BCR) sequential extraction ((A): Cd long-term; (B): Cd short-term; (C): Pb long-term; (D): Pb short-term). $\mathrm{B} 1$ = Exchangeable fraction; $\mathrm{B} 2=$ Iron and manganese oxyhydroxides fraction; B3 = Organic fraction; B4 = Residual fraction.

\subsection{Biochar Effects on SOM, $p H$ and Water Content}

Changes in soil properties, as a function of biochar application rate in the long-and short-term experiments, are shown in Figure 2. The SOM content significantly increased by 8.1-38.5\% (long-term) and 3.9-49.3\% (short-term), related to increasing biochar application rate (Figure 2A). The long- and short-term SOM changes remained statistically unchanged over time. Others have also noted similar SOM responses due to biochar application. For example, orchard prunings biochar $(10 \%, v: v)$ reduced exchangeable metal concentrations in soil, which in part was attributed to increasing SOM [40].

Soil water contents were also significantly affected by increasing biochar application rates (Figure 2B). Soil water content increased by 3.8-41.6\% (long-term, except 2016) and 4.5-77.4\% (short-term), suggesting that biochar application may have improved soil physical properties. Positive changes in soil water content via biochar application have been observed by others [41-44].

Increasing biochar application rates also significantly increased soil $\mathrm{pH}$, with soil $\mathrm{pH}$ having been shown to directly influence heavy metal fractions [45]. Soil pH significantly increased by $0.05-0.31 \mathrm{pH}$ units (long-term) and $0.07-0.35 \mathrm{pH}$ units (short-term), with greater changes associated with greater biochar application rates. The short-term usually had a greater effect on increasing soil $\mathrm{pH}$ compared to the long-term under the same treatment (Figure $2 \mathrm{C}$ ). Increasing soil $\mathrm{pH}$ has been found to be a key factor for reducing heavy metal bioavailability $[15,46]$. 

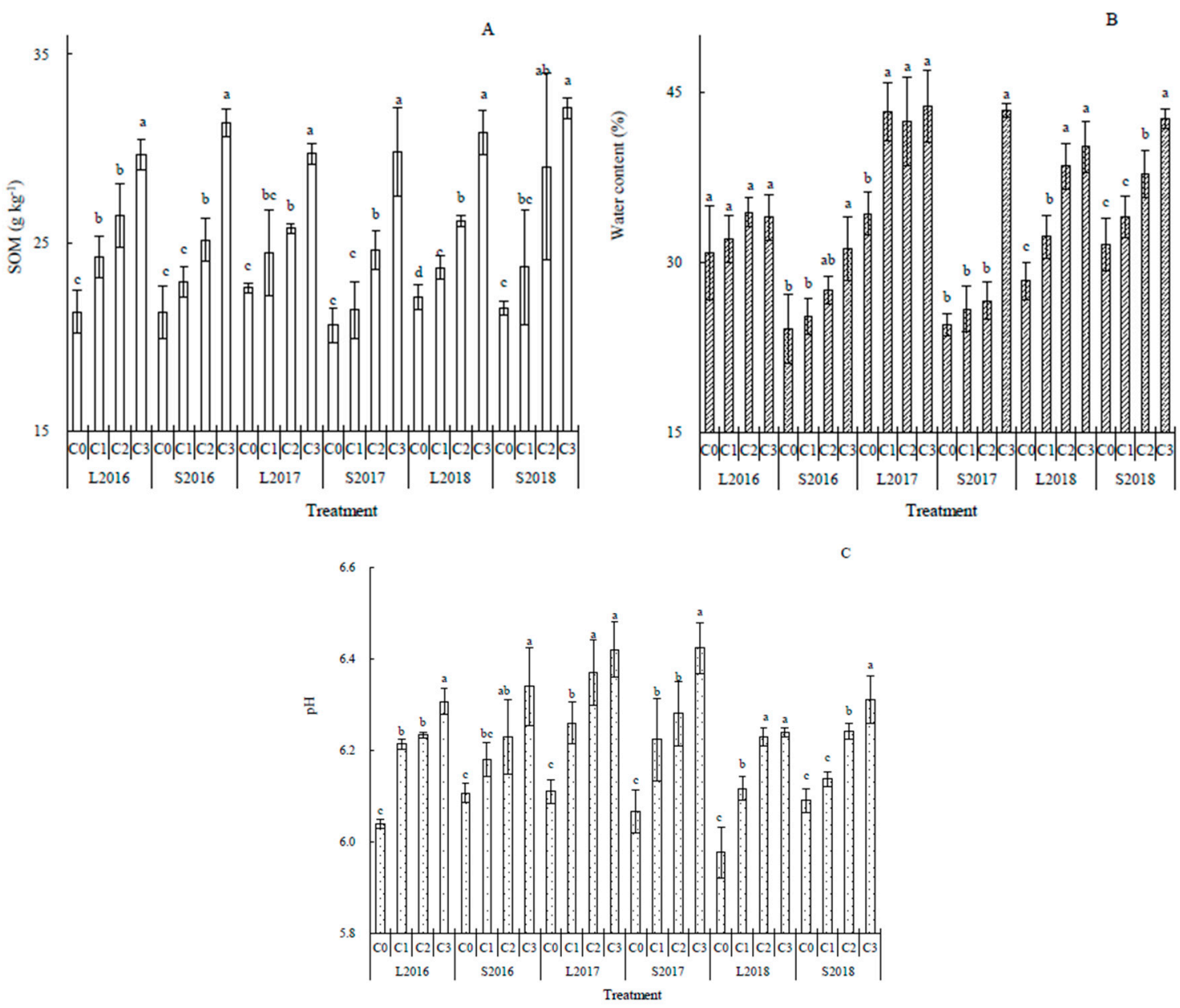

Figure 2. The effect of long- (L) and short-term (S), increasing biochar application rates $[0(\mathrm{C} 0), 10(\mathrm{C} 1)$, 20 (C2) and 40 (C3) t ha ${ }^{-1}$ ] on soil (A) SOM, (B) water content, and (C) pH at rice harvest. Different lower-case letters above error bars indicate significant differences between the biochar treatments in either the short- or long-term for a given year $[p<0.05$, Least significant difference (LSD) post-hoc test]. Error bars represent standard deviation of the mean $(n=3)$.

\subsection{Biochar Effects on $\mathrm{Cd}$ and $\mathrm{Pb}$ Transfer in Rice}

The $\mathrm{Cd}$ and $\mathrm{Pb}$ concentrations in rice, as a function of biochar application rate in the long- and short-term, are shown in Figure 3. Following either short- or long-term biochar application at $40 \mathrm{tha}{ }^{-1}$, rice $\mathrm{Cd}$ and $\mathrm{Pb}$ concentrations decreased by $30.7 \%$ and $45.2 \%$ (2016), 45.0\% and $40.0 \%$ (2017), and $84.1 \%$ and $28.1 \%$ (2018), respectively, as compared to the control; lesser reductions were observed with lower biochar application rates. The rice husk, stem and root $\mathrm{Cd}$ and $\mathrm{Pb}$ concentrations followed similar trends. Biochar significantly reduced $\mathrm{Cd}$ and $\mathrm{Pb}$ transfer from roots to stems to grain; root $\mathrm{Cd}$ and $\mathrm{Pb}$ concentrations were over $40 \mathrm{mg} \mathrm{kg}^{-1}$ and $300 \mathrm{mg} \mathrm{kg}^{-1}$, respectively, yet rice grain $\mathrm{Cd}$ and $\mathrm{Pb}$ concentrations were approaching or met national food safety level $\left(\leq 0.2 \mathrm{mg} \mathrm{kg}^{-1}\right)$ [47]. Other studies have shown that brinjal (i.e., eggplant) fruit $\mathrm{Cd}$ concentrations can be significantly decreased (up to $86.6 \%)$ using miscanthus biochar $(1.5 \%, w: w)$ [48].

The BCF and TF were used to assess $\mathrm{Cd}$ and $\mathrm{Pb}$ transfer from the soil to the above-ground plant, and from plant roots to above-ground tissues, respectively. The BCF decreased by up to $77.1 \%(\mathrm{Cd})$ and $33.2 \%(\mathrm{~Pb})$ in the long-term, and by up to $45.7 \%(\mathrm{Cd})$ and $42.3 \%(\mathrm{~Pb})$ in the short-term. The TF also decreased by up to $53.2 \%(\mathrm{Cd})$ and $17.1 \%(\mathrm{~Pb})$ in the long-term, and by up to $21.9 \%(\mathrm{Cd})$ and $23.2 \%(\mathrm{~Pb})$ in the short-term (Table S2). The trend of decreasing BCF and TF with increasing biochar application rate supports our previous findings that biochar can reduce $\mathrm{Cd}$ and $\mathrm{Pb}$ bioavailability, suggesting that biochar may play a role in decreasing $\mathrm{Cd}$ and $\mathrm{Pb}$ transfer in the food chain [49]. Similar to our study, 
Mujtaba Munir et al., found that the bamboo biochar treatments reduced TF Cd and Pb by $49.6-61.0 \%$ and $61.0-70.7 \%$, respectively, as compared to a control [21]; findings suggested that biochar effectively reduced bioavailable metal phases, leading to reduced metal translocation within plants.
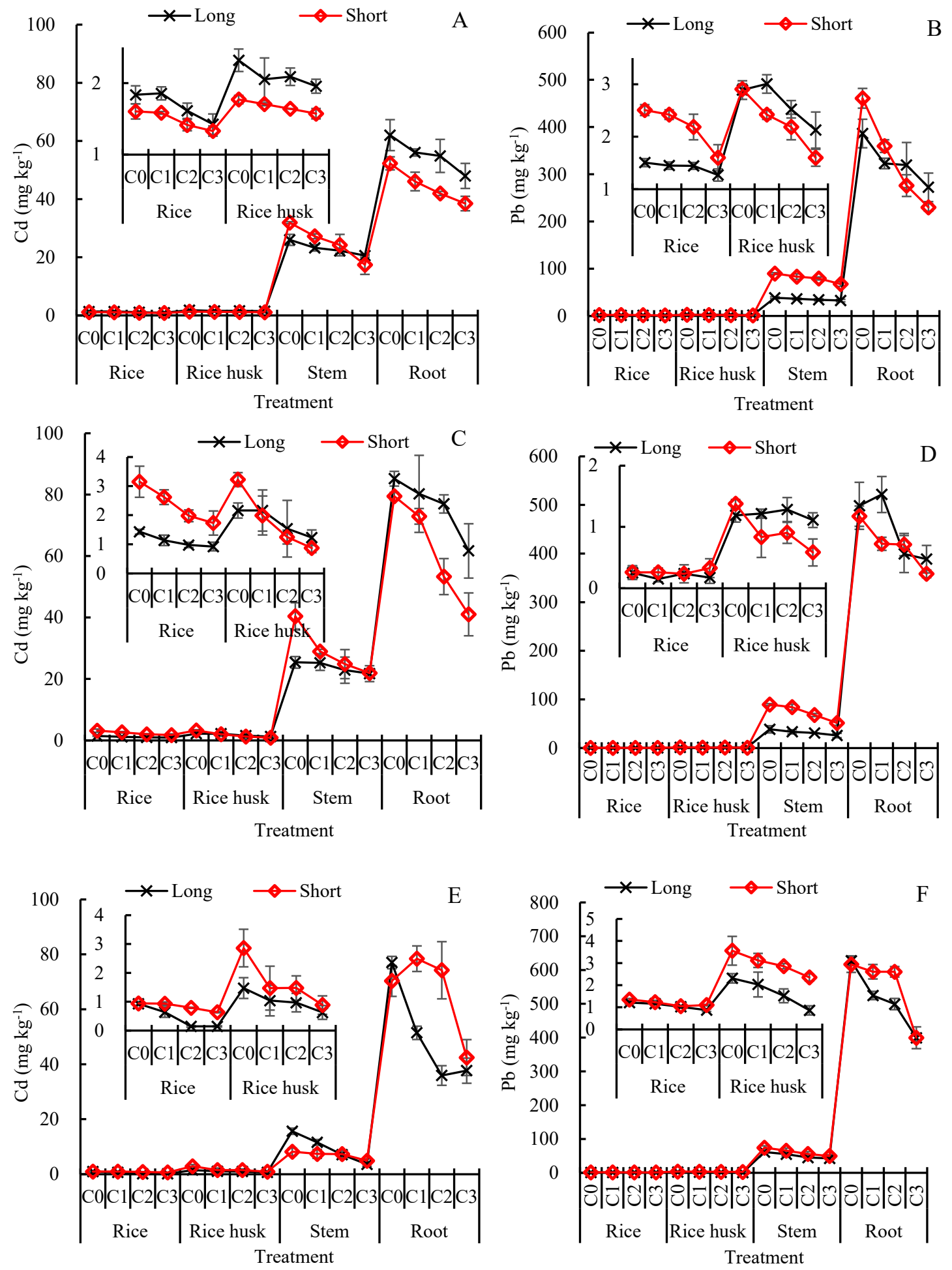

Figure 3. The effect of long- and short-term, increasing biochar application rates [0 (C0), 10 (C1), 20 (C2) and 40 (C3) $\mathrm{t} \mathrm{ha}^{-1}$ ] on $\mathrm{Cd}$ and $\mathrm{Pb}$ distribution in rice over time ((A): $2016 \mathrm{Cd} ;(\mathbf{B}): 2016 \mathrm{~Pb} ;(\mathbf{C}): 2017$ Cd; (D): 2017 Pb; (E): 2018 Cd; (F): 2018 Pb; Long: long-term; Short: short-term). Error bars represent standard deviation of the mean $(n=3)$. 


\subsection{Biochar Effects on Soil Enzyme Activity and Microbial Diversity}

Soil enzyme activities are key indicators of ecological change, and are particularly sensitive to anthropogenic modifications of heavy metal contaminated soils. Enzymatic activity alterations, due to soil amendment applications, are directly expressed in strength of biochemical reactions and their associated implications within soils [50]. In particular, soil oxidoreductase enzymatic activities are sensitive to change, and include alkaline phosphatase, dehydrogenase, urease and sucrase enzymatic activities. Specifically, Tabatabai suggest that alkaline phosphatase describes a broad group of enzymes that catalyze the hydrolysis of both ester and anhydride organic $\mathrm{P}$, leading to increased inorganic $\mathrm{P}$ availability [51]. Dehydrogenase activity is typically considered a measure of general microbial activity [52]. Urease activity has long been known to hydrolyze urea to ammonium [53], thus increasing $\mathrm{N}$ availability to plants. And, sucrase activity is involved in sucrose degradation as well as direct SOM metabolism, which would enhance nutrient availability [54].

Soil enzymatic activities, as a function of biochar application rate in the long- and short-term, are shown in Figure 4. Biochar applications led to increased enzymatic activities in this $\mathrm{Cd}$ and $\mathrm{Pb}$ contaminated soil. Increasing biochar application rate increased: (a) phosphatase enzyme activity by $8.8-104.9 \%$ (long-term) and 9.0-83.6\% (short-term); (b) dehydrogenase enzyme activity by $9.3-118.5 \%$ (long-term) and 10.4-103.5\% (short-term); and (c) urease and sucrase enzyme activity by $91.3 \%$ and $77.9 \%$ (long-term), $132.4 \%$ and $83.6 \%$ (short-term), respectively. One could construe increased enzymatic activities as indicators of positive ecosystem change.
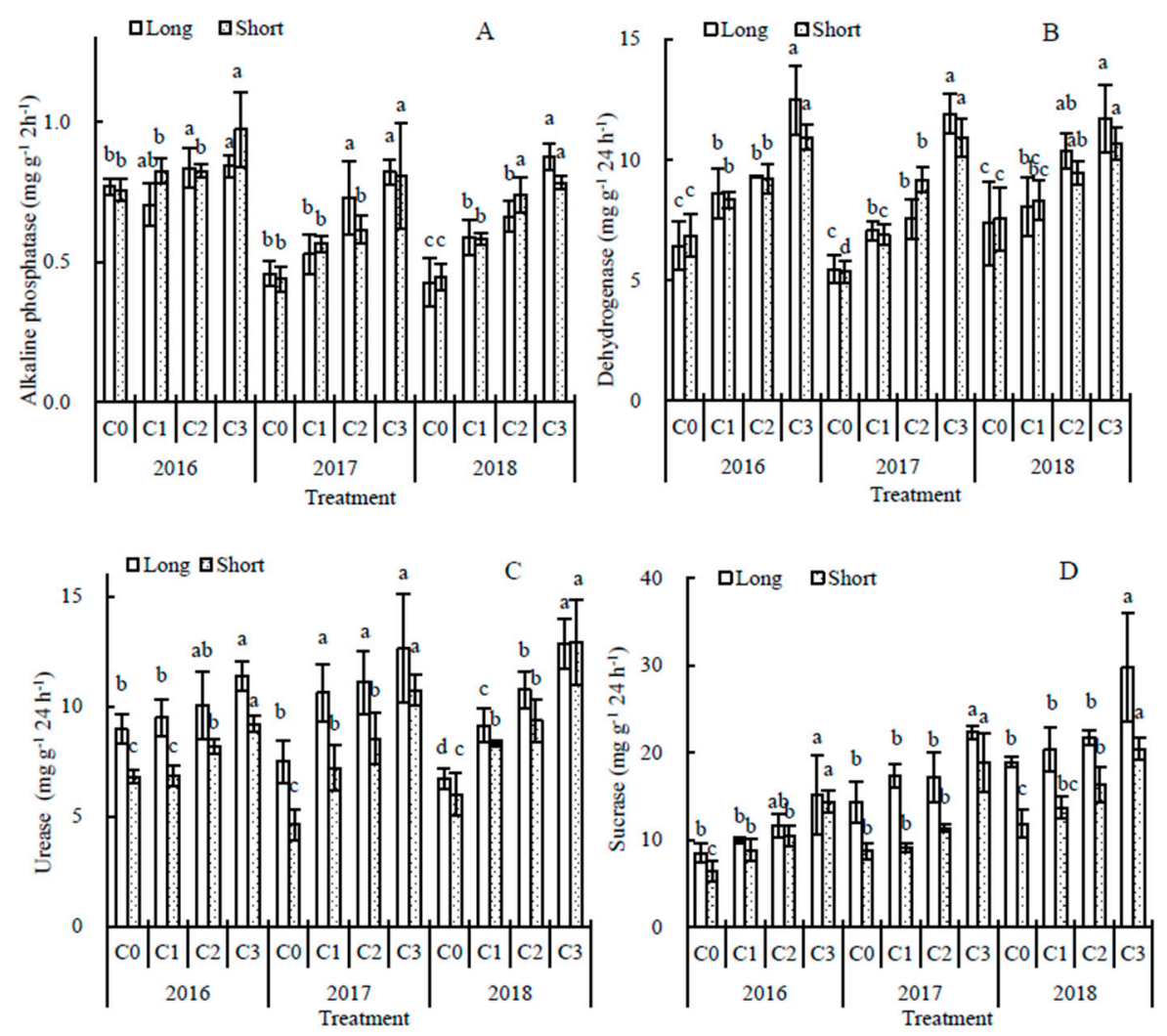

Figure 4. The effect of long- and short-term, increasing biochar application rates [0 (C0), 10 (C1), 20 (C2) and 40 (C3) t ha ${ }^{-1}$ ] on (A) alkaline phosphatase, (B) dehydrogenase, (C) urease, and (D) sucrase activity. Different lower-case letters above error bars indicate significant differences between the biochar treatments in either the short- or long-term for a given year $(p<0.05$, LSD post-hoc test). The error bars represent standard deviation of the mean $(n=3)$. 
Others have also noted enzymatic activity changes associated with biochar application. Chen et al., showed that wood biochar (4\%, w:w) increased sucrase activity by up to 12.5-fold as compared to a control, with a subsequent improvement in soil fertility status [55]. Biochar amendment caused both catalase and urease activities to gradually decrease up to 45 days, but then increased over longer timeframes [18]. However, others biochar studies have found opposite responses. Liu et al., reported decreased urease activity in biochar amended soils, likely the result of oxidative reactions with free radicals on biochar surfaces [56]. Huang et al., utilized rice straw biochar $(5 \%, w: w)$, observing a decrease in urease and alkaline phosphatase activities [57]. Regardless, in our study, biochar applications appear to cause positive changes in soil enzymatic activity, and thus biochar use may lead to positive changes in ecosystem functionality.

Increasing biochar application rates tended to increase the Shannon microbial diversity index in both the long- and short-term (Figure 5A). The Shannon index increased by $8.2 \%$ and $3.4 \%$ (2016), and by $46.2 \%$ and $29.8 \%$ (2017) in the long- and short-term studies, with greatest changes associated with the highest biochar application rate. Similar Shannon diversity index changes associate with bacterial communities in biochar amended soils have been previously reported [58]. Zhang et al., found that biochar application $(1.5 \%)$ had the highest richness estimators and Shannon diversity index in amended, Cd contaminated soil [59].
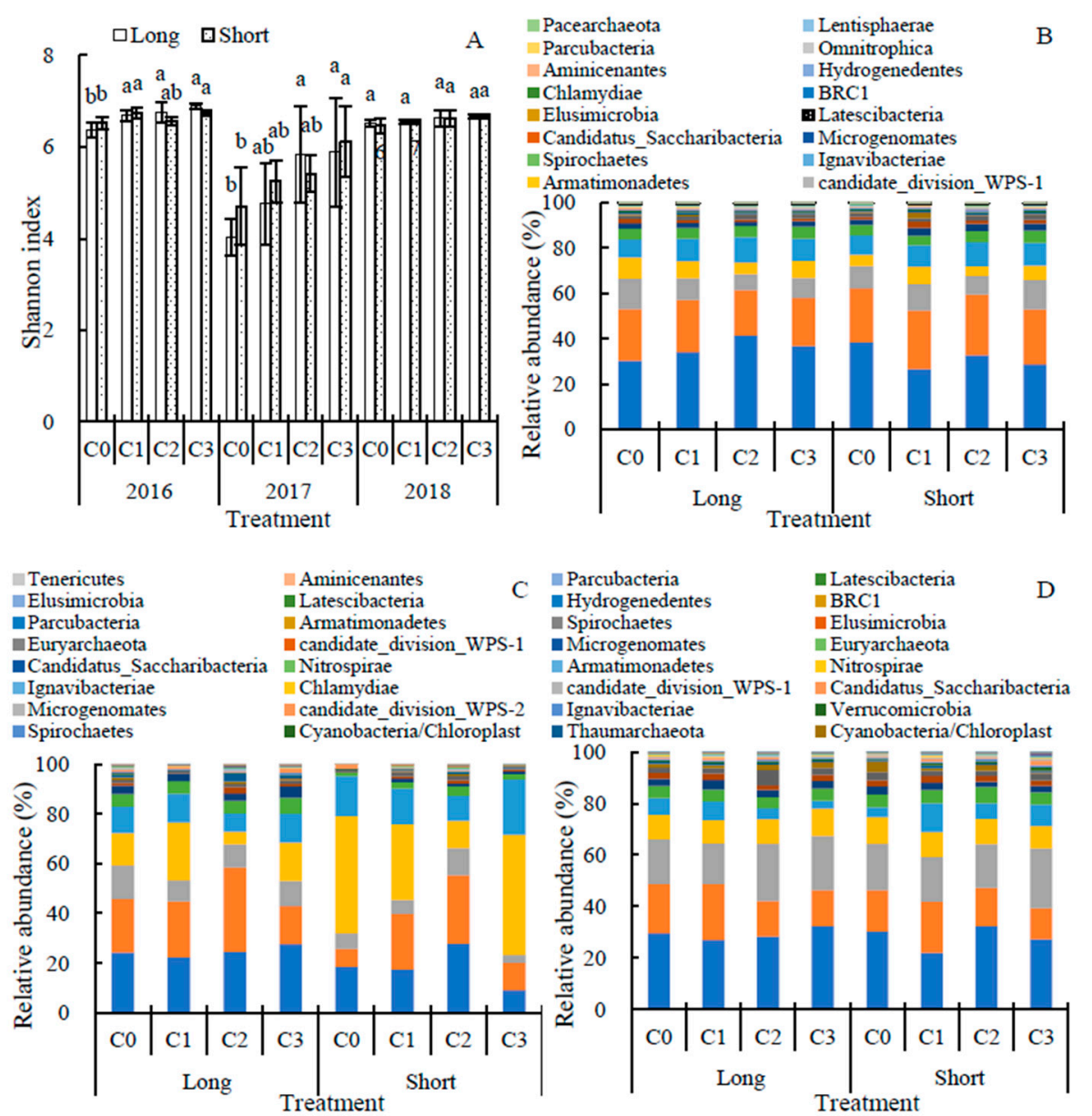

Figure 5. The effect of long- and short-term, increasing biochar application rates [0 (C0), 10 (C1), 20 (C2) and 40 (C3) tha ${ }^{-1}$ ] on changes of the (A) Shannon index and soil microbial diversity ((B): 2016; (C): 2017; (D): 2018). Different lower-case letters above error bars indicate significant differences between the biochar treatments in either the short- or long-term for a given year $(p<0.05$, LSD post-hoc test). The error bars represent standard deviation of the mean $(n=3)$. 
High-throughput PCR screening was used to further distinguish changes in microbial diversity (Figure 5B-D). During the studied years, microbial diversity increased by over $90 \%$ compared at phylum level. Steinbeiss et al., found similar responses due to biochar application. In the current study, biochar had the greatest effect on nine-phylum level microbial diversities in the short-term, significantly increasing them by $9.4-102.9 \%$ compared to the control (except Chloroflexi in the short-term in 2016) [60]. The nine-phylum level microbial diversities were slightly decreased by $6.4-46.9 \%$ in the long-term, except Chloroflexi, Acidobacteria, Unassigned and Gemmatimonadetes. Biochar $(2 \%, w: w)$ has been shown to provide a positive effect on bacteria and invertebrate (such as earthworm) growth in heavy metal-contaminated agricultural soil in the short-term [2]. In a lab experiment, bacterial counts were increased by $149.4 \%$ compared with a control after 63 days following coconut shell biochar ( $5 \%$, w:w) application to a Cd and Zn contaminated soil [38]. As with previous studies, in the current study, the soil microbial diversity was more greatly influenced in the short- versus long-term.

\subsection{The Influence of Biochar on Soil and Plant Characteristics in Relation to $\mathrm{Cd}$ and Pb Contamination}

Biochar application improved soil properties and reduced above-ground rice plant metals concentrations, with direct or indirect pathways illustrated via PCA and correlation analysis (Figure 6). The PCA results shown that biochar application rates were positively related to soil properties (e.g., SOM, pH), soil enzyme activity and soil moisture factors in PC1 (32.9\%). Negative relationships between biochar applications and $\mathrm{Cd}$ and $\mathrm{Pb}$ concentrations in the soil exchangeable phase, and $\mathrm{Cd}$ and $\mathrm{Pb}$ concentrations in crops, were also observed in PC1. The factors of PC2 mainly included organic and residual $\mathrm{Cd}$ and $\mathrm{Pb}$ fractions and microbial diversity, which were positively related to biochar application rates. The factors of PC1 and PC2 explained $72 \%$ of the variability for all factors, indicating that biochar was one of the key factors affecting soil properties, various soil $\mathrm{Cd}$ and $\mathrm{Pb}$ fractions, and microbial diversity. Similarly, Tang et al., found that rice straw biochar application was effective at improving soil $\mathrm{pH}$ and $\mathrm{SOM}$, leading to decreased $\mathrm{Cd}$ availability and subsequent increases in soil enzymatic activity [61]. Xing et al., showed that a sludge-based biochar increased the ratio of immobilized soil heavy metals, which positively correlated to the presence of $V$. fischeri, the growth of wheat, and the activities of other soil microbes [39].

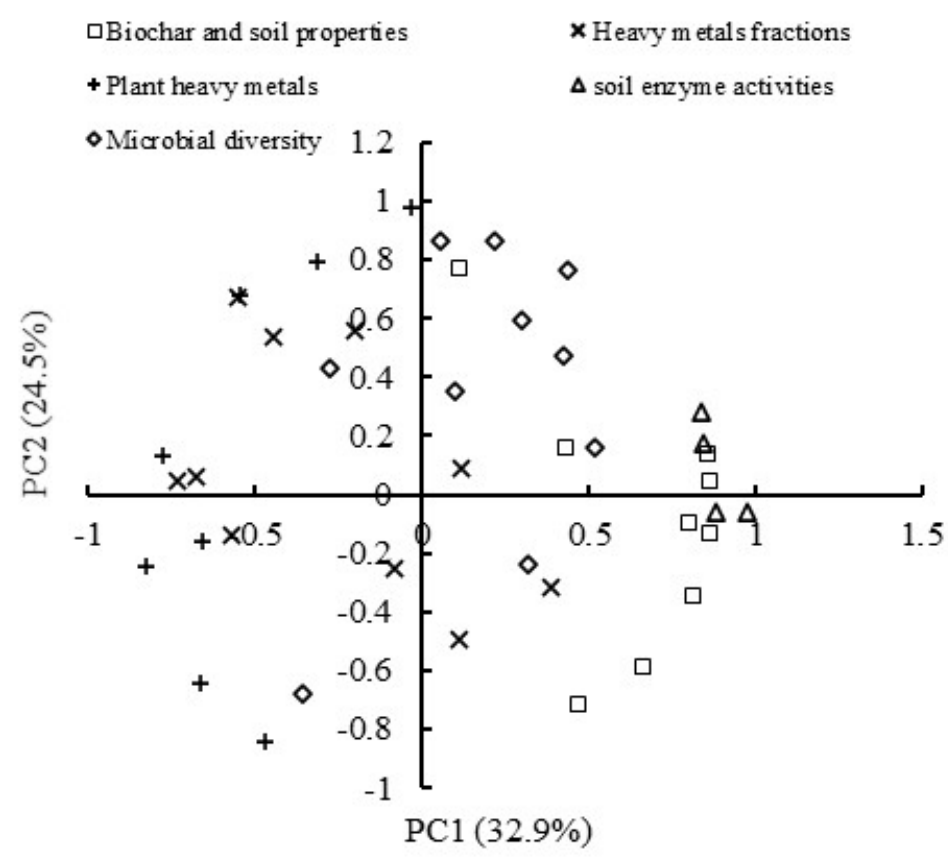

Figure 6. A principle component analysis. 


\section{Conclusions}

Study results supported the hypothesis that wheat straw biochar could be used to decrease soil $\mathrm{Cd}$ and $\mathrm{Pb}$ bioavailability, decrease $\mathrm{Cd}$ and $\mathrm{Pb}$ uptake and translocation by rice, and improve a contaminated soil's overall bio-physicochemical characteristics. Biochar improved soil moisture content, increased soil $\mathrm{pH}, \mathrm{SOM}$, and reduced $\mathrm{Cd}$ and $\mathrm{Pb}$ bioavailability. Furthermore, biochar transformed bioavailable $\mathrm{Cd}$ and $\mathrm{Pb}$ to residual (i.e., unavailable) phases. In turn, biochar helped reduce the $\mathrm{BCF}$ and $\mathrm{TF}$ within rice, and reduced grain $\mathrm{Cd}$ and $\mathrm{Pb}$ concentrations to near or below China's national safety concentrations. Other positive responses were observed with respect to greater soil enzymatic activity and microbial community structure, although some positive changes were more evident over shorter (versus longer) time periods following biochar application. Future research should focus on atomic-level mechanisms (e.g., synchrotron-based studies) by which biochar sorbs and stabilizes long-term, in-situ heavy metals over longer time periods and in different soil types.

Supplementary Materials: The following are available online at http://www.mdpi.com/2076-3298/7/7/53/s1, Figure S1: the schematic diagram fo the acceptor cell title, Figure S2: The effect of long- and short-term, increasing biochar application rates [0(C0), 10 (C1), 20 (C2) and 40 (C3) $\mathrm{t} \mathrm{ha}^{-1}$ ] on water-soluble $\mathrm{Cd}$ and $\mathrm{Pb}$ with in-situ different time (A: Cd long-term; B: Cd short-term; C: Pb long-term; D: Pb short-term), Table S1: Basic paddy soil ( 0 to $15 \mathrm{~cm}$ depth) and biochar $\left(\mathrm{g} \mathrm{kg}^{-1}\right)$ properties, Table S2: Bioconcentration (BCF) and translocation (TF) factors associated with biochar amend soil (biochar rates $=0(\mathrm{C} 0), 10(\mathrm{C} 1), 20$ (C2) and 40 (C3) $\mathrm{t} \mathrm{ha}^{-1}$ ).

Author Contributions: Conceptualization, L.C., L.L. and J.Y.; writing-original draft preparation, L.C. and R.B.; formal analysis, L.C., G.Q. and Y.L.; investigation, Y.L.; resources, L.C. and H.W.; review and editing, J.A.I. and L.C.; visualization, H.W.; supervision, L.L. and J.Y.; funding acquisition, L.C. and J.Y. All authors have read and agreed to the published version of the manuscript.

Funding: This study received funding from the National Natural Science Foundation of China: 41501339, National Natural Science Foundation of China: 21677119, Jiangsu Province Science Foundation for Youths: BK20140468 and from the QingLan Project.

Conflicts of Interest: The authors declare no conflict of interest.

\section{References}

1. Cui, L.; Noerpel, M.; Scheckel, K.G.; Ippolito, J.A. Wheat straw biochar reduces environmental cadmium bioavailability. Environ. Int. 2019, 126, 69-75. [CrossRef] [PubMed]

2. Hale, S.E.; Jensen, J.; Jakob, L.; Oleszczuk, P.; Hartnik, T.; Henriksen, T.; Okkenhaug, G.; Martinsen, V.; Cornelissen, G. Short-Term Effect of the Soil Amendments Activated Carbon, Biochar, and Ferric Oxyhydroxide on Bacteria and Invertebrates. Environ. Sci. Technol. 2013, 47, 8674-8683. [CrossRef] [PubMed]

3. MEP; MLR. The national soil contamination survey. Natl. Soil Pollut. Surv. Bull. 2014, 4, 1-5.

4. Shen, Z.; Jin, F.; O'Connor, D.; Hou, D. Solidification/Stabilization for Soil Remediation: An Old Technology with New Vitality. Environ. Sci. Technol. 2019, 53, 11615-11617. [CrossRef]

5. Wang, L.; Yu, K.; Li, J.; Tsang, D.C.W.; Poon, C.S.; Yoo, J.; Baek, K.; Ding, S.; Hou, D.; Dai, J. Low-carbon and low-alkalinity stabilization/solidification of high-Pb contaminated soil. Chem. Eng. J. 2018, 351, 418-427. [CrossRef]

6. Senneca, O.; Cortese, L.; Di Martino, R.; Fabbricino, M.; Ferraro, A.; Race, M.; Scopino, A. Mechanisms affecting the delayed efficiency of cement based stabilization/solidification processes. J. Clean. Prod. 2020, 261, 121230. [CrossRef]

7. Cui, L.Q.; Li, L.Q.; Zhang, A.F.; Pan, G.X.; Bao, D.D.; Chang, A. Biochar Amendment Greatly Reduces Rice Cd Uptake in a Contaminated Paddy Soil: A Two-Year Field Experiment. Bioresources 2011, 6, 2605-2618.

8. Ippolito, J.A.; Laird, D.A.; Busscher, W.J. Environmental Benefits of Biochar. J. Environ. Qual. 2012, 41, 967-972. [CrossRef]

9. Lehmann, J.; Rillig, M.C.; Thies, J.E.; Masiello, C.A.; Hockaday, W.C.; Crowley, D.E. Biochar effects on soil biota-A review. Soil Biol. Biochem. 2011, 43, 1812-1836. [CrossRef]

10. Li, X.; Wang, C.; Zhang, J.; Liu, J.; Liu, B.; Chen, G. Preparation and application of magnetic biochar in water treatment: A critical review. Sci. Biochem. Environ. 2020, 711, 134847. [CrossRef] 
11. Khan, Z.H.; Gao, M.; Qiu, W.; Islam, M.S.; Song, Z. Mechanisms for cadmium adsorption by magnetic biochar composites in an aqueous solution. Chemosphere 2020, 246, 125701. [CrossRef] [PubMed]

12. Hemavathy, R.V.; Kumar, P.S.; Kanmani, K.; Jahnavi, N. Adsorptive separation of Cu(II) ions from aqueous medium using thermally/chemically treated Cassia fistula based biochar. J. Clean. Prod. 2020, 249, 119390. [CrossRef]

13. Zhao, L.; Nan, H.; Kan, Y.; Xu, X.; Qiu, H.; Cao, X. Infiltration behavior of heavy metals in runoff through soil amended with biochar as bulking agent. Environ. Pollut. 2019, 254, 113114. [CrossRef]

14. Qin, P.; Wang, H.; Yang, X.; He, L.; Müller, K.; Shaheen, S.M.; Xu, S.; Rinklebe, J.; Tsang, D.C.W.; Ok, Y.S.; et al. Bamboo- and pig-derived biochars reduce leaching losses of dibutyl phthalate, cadmium, and lead from co-contaminated soils. Chemosphere 2018, 198, 450-459. [CrossRef] [PubMed]

15. Ippolito, J.A.; Berry, C.M.; Strawn, D.G.; Novak, J.M.; Levine, J.; Harley, A. Biochars Reduce Mine Land Soil Bioavailable Metals. J. Environ. Qual. 2017, 46, 411-419. [CrossRef]

16. Chen, D.; Wang, X.; Wang, X.; Feng, K.; Su, J.; Dong, J. The mechanism of cadmium sorption by sulphur-modified wheat straw biochar and its application cadmium-contaminated soil. Sci. Total Environ. 2020, 714, 136550. [CrossRef]

17. Yin, D.; Wang, X.; Chen, C.; Peng, B.; Tan, C.; Li, H. Varying effect of biochar on Cd, Pb and As mobility in a multi-metal contaminated paddy soil. Chemosphere 2016, 152, 196-206. [CrossRef]

18. Tu, C.; Wei, J.; Guan, F.; Liu, Y.; Sun, Y.; Luo, Y. Biochar and bacteria inoculated biochar enhanced Cd and Cu immobilization and enzymatic activity in a polluted soil. Environ. Int. 2020, 137, 105576. [CrossRef]

19. Bian, R.; Joseph, S.; Cui, L.; Pan, G.; Li, L.; Liu, X.; Zhang, A.; Rutlidge, H.; Wong, S.; Chia, C. A three-year experiment confirms continuous immobilization of cadmium and lead in contaminated paddy field with biochar amendment. J. Hazard. Mater. 2014, 272, 121-128. [CrossRef]

20. Zhang, L.; Tang, S.; Jiang, C.; Jiang, X.; Guan, Y. Simultaneous and Efficient Capture of Inorganic Nitrogen and Heavy Metals by Polyporous Layered Double Hydroxide and Biochar Composite for Agricultural Nonpoint Pollution Control. ACS Appl. Mater. Interfaces 2018, 10, 43013-43030. [CrossRef]

21. Mujtaba Munir, M.A.; Liu, G.; Yousaf, B.; Ali, M.U.; Abbas, Q.; Ullah, H. Synergistic effects of biochar and processed fly ash on bioavailability, transformation and accumulation of heavy metals by maize (Zea mays L.) in coal-mining contaminated soil. Chemosphere 2020, 240, 124845. [CrossRef] [PubMed]

22. Cui, L.; Pan, G.; Li, L.; Yan, J.; Zhang, A.; Bian, R.; Chang, A. The Reduction of Wheat Cd Uptake in Contaminated Soil Via Biochar Amendment: A Two-Year Field Experiment. Bioresources 2012, 7, 5666-5676. [CrossRef]

23. Cui, L.; Pan, G.; Li, L.; Bian, R.; Liu, X.; Yan, J.; Quan, G.; Ding, C.; Chen, T.; Liu, Y.; et al. Continuous immobilization of cadmium and lead in biochar amended contaminated paddy soil: A five-year field experiment. Ecol. Eng. 2016, 93, 1-8. [CrossRef]

24. Gong, Z.; Lei, W.; Chen, Z.; Gao, Y.; Zeng, S.; Zhang, G.; Xiao, D.; Li, S. Chinese Soil Taxonomy. Bull. Chin. Acad. Sci. 2007, 21, 36-38.

25. Lu, R. Methods of inorganic pollutants analysis. In Soil and Agro-Chemical Analysis Methods; Agricultural Science and Technology Press: Beijing, China, 2000; pp. 205-266.

26. Parat, C.; Pinheiro, J.P. ISIDORE, a probe for in situ trace metal speciation based on Donnan membrane technique with related electrochemical detection part 1: Equilibrium measurements. Anal. Chim. Acta 2015, 896, 1-10. [CrossRef]

27. Ure, A.M.; Quevauviller, P.; Muntau, H.; Griepink, B. Speciation of Heavy Metals in Soils and Sediments. An Account of the Improvement and Harmonization of Extraction Techniques Undertaken Under the Auspices of the BCR of the Commission of the European Communities. Int. J. Environ. Anal. Chem. 1993, 51, 135-151. [CrossRef]

28. Wang, Y.-P.; Shi, J.-Y.; Qi, L.; Chen, X.-C.; Chen, Y.-X. Heavy metal availability and impact on activity of soil microorganisms along a Cu/Zn contamination gradient. J. Environ. Sci. 2007, 19, 848-853. [CrossRef]

29. Cui, L.; Yan, J.; Yang, Y.; Li, L.; Quan, G.; Ding, C.; Chen, T.; Fu, Q.; Chang, A. Influence of biochar on microbial activities of heavy metals contaminated paddy fields. BioResources 2013, 8, 5536-5548. [CrossRef]

30. Gong, X.; Jiang, Y.; Zheng, Y.; Chen, X.; Li, H.; Hu, F.; Liu, M.; Scheu, S. Earthworms differentially modify the microbiome of arable soils varying in residue management. Soil Biol. Biochem. 2018, 121, 120-129. [CrossRef] 
31. van Leeuwen, H.P.; Town, R.M.; Buffle, J.; Cleven, R.F.M.J.; Davison, W.; Puy, J.; van Riemsdijk, W.H.; Sigg, L. Dynamic Speciation Analysis and Bioavailability of Metals in Aquatic Systems. Environ. Sci. Technol. 2005, 39, 8545-8556. [CrossRef]

32. Fan, Q.; Sun, J.; Quan, G.; Yan, J.; Gao, J.; Zou, X.; Cui, L. Insights into the effects of long-term biochar loading on water-soluble organic matter in soil: Implications for the vertical co-migration of heavy metals. Environ. Int. 2020, 136, 105439. [CrossRef]

33. Xu, Y.; Seshadri, B.; Sarkar, B.; Wang, H.; Rumpel, C.; Sparks, D.; Farrell, M.; Hall, T.; Yang, X.; Bolan, N. Biochar modulates heavy metal toxicity and improves microbial carbon use efficiency in soil. Sci. Total Environ. 2018, 621, 148-159. [CrossRef] [PubMed]

34. Wang, Y.; Zhong, B.; Shafi, M.; Ma, J.; Guo, J.; Wu, J.; Ye, Z.; Liu, D.; Jin, H. Effects of biochar on growth, and heavy metals accumulation of moso bamboo (Phyllostachy pubescens), soil physical properties, and heavy metals solubility in soil. Chemosphere 2019, 219, 510-516. [CrossRef] [PubMed]

35. Zhang, Y.; Chen, Z.; Xu, W.; Liao, Q.; Zhang, H.; Hao, S.; Chen, S. Pyrolysis of various phytoremediation residues for biochars: Chemical forms and environmental risk of $\mathrm{Cd}$ in biochar. Bioresour. Technol. 2020, 299, 122581. [CrossRef]

36. Chen, Q.; Dong, J.; Yi, Q.; Liu, X.; Zhang, J.; Zeng, Z. Proper Mode of Using Rice Straw Biochar To Treat Cd-Contaminated Irrigation Water in Mining Regions Based on a Multiyear in Situ Experiment. ACS Sustain. Chem. Eng. 2019, 7, 9928-9936. [CrossRef]

37. Wang, Y.; Xu, Y.; Li, D.; Tang, B.; Man, S.; Jia, Y.; Xu, H. Vermicompost and biochar as bio-conditioners to immobilize heavy metal and improve soil fertility on cadmium contaminated soil under acid rain stress. Sci. Total Environ. 2018, 621, 1057-1065. [CrossRef]

38. Liu, H.; Xu, F.; Xie, Y.; Wang, C.; Zhang, A.; Li, L.; Xu, H. Effect of modified coconut shell biochar on availability of heavy metals and biochemical characteristics of soil in multiple heavy metals contaminated soil. Sci. Total Environ. 2018, 645, 702-709. [CrossRef]

39. Xing, J.; Li, L.; Li, G.; Xu, G. Feasibility of sludge-based biochar for soil remediation: Characteristics and safety performance of heavy metals influenced by pyrolysis temperatures. Ecotoxicol. Environ. Saf. 2019, 180, 457-465. [CrossRef]

40. Beesley, L.; Inneh, O.S.; Norton, G.J.; Moreno-Jimenez, E.; Pardo, T.; Clemente, R.; Dawson, J.J.C. Assessing the influence of compost and biochar amendments on the mobility and toxicity of metals and arsenic in a naturally contaminated mine soil. Environ. Pollut. 2014, 186, 195-202. [CrossRef]

41. Novak, J.M.; Busscher, W.J.; Watts, D.W.; Amonette, J.E.; Ippolito, J.A.; Lima, I.M.; Gaskin, J.W.; Das, K.C.; Steiner, C.; Ahmedna, M. Biochars impact on soil moisture storage in an Ultisol and two Aridisols. Soil Sci. 2012, 177, 310-320. [CrossRef]

42. Ippolito, J.A.; Stromberger, M.E.; Lentz, R.D.; Dungan, R.S. Hardwood biochar influences calcareous soil physicochemical and microbiological status. J. Environ. Qual. 2014, 43, 681-689. [CrossRef] [PubMed]

43. Ippolito, J.A.; Stromberger, M.E.; Lentz, R.D.; Dungan, R.S. Hardwood biochar and manure co-application to a calcareous soil. Chemosphere 2016, 142, 84-91. [CrossRef] [PubMed]

44. Lentz, R.D.; Ippolito, J.A.; Lehrsch, G.A. Biochar, Manure, and Sawdust Alter Long-Term Water Retention Dynamics in Degraded Soil. Soil Sci. Soc. Am. J. 2019, 83, 1491-1501. [CrossRef]

45. Liu, S.; Pu, S.; Deng, D.; Huang, H.; Yan, C.; Ma, H.; Razavi, B.S. Comparable effects of manure and its biochar on reducing soil $\mathrm{Cr}$ bioavailability and narrowing the rhizosphere extent of enzyme activities. Environ. Int. 2020, 134, 105277. [CrossRef] [PubMed]

46. Wang, F.; Wang, H.; Al-Tabbaa, A. Leachability and heavy metal speciation of 17-year old stabilised/solidified contaminated site soils. J. Hazard. Mater. 2014, 278, 144-151. [CrossRef]

47. NHFPC; CFDA. National Standards for Food Safety Limits for Contaminants in Food; China Food and Drug Administration Press: Beijing, China, 2017; pp. 2-5.

48. Turan, V.; Khan, S.A.; Mahmood ur, R.; Iqbal, M.; Ramzani, P.M.A.; Fatima, M. Promoting the productivity and quality of brinjal aligned with heavy metals immobilization in a wastewater irrigated heavy metal polluted soil with biochar and chitosan. Ecotoxicol. Environ. Saf. 2018, 161, 409-419. [CrossRef]

49. Puga, A.P.; Abreu, C.A.; Melo, L.C.A.; Beesley, L. Biochar application to a contaminated soil reduces the availability and plant uptake of zinc, lead and cadmium. J. Environ. Manag. 2015, 159, 86-93. [CrossRef] 
50. Bandara, T.; Franks, A.E.; Xu, J.; Bolan, N.; Wang, H.; Tang, C. Chemical and biological immobilization mechanisms of potentially toxic elements in biochar-amended soils. Crit. Rev. Environ. Sci. Technol. 2019, 50, 903-978. [CrossRef]

51. Tabatabai, M.A. Soil enzymes. In Methods of Soil Analysis, Part 2. Microbiological and Biochemical Properties; SSSA Book Series No. 5; Weaver, R.W., Angle, J.S., Bottomley, P.S., Eds.; Soil Science Society of America: Madison, WI, USA, 1994; pp. 775-833.

52. Moeskops, B.; Sukristiyonubowo; Buchan, D.; Sleutel, S.; Herawaty, L.; Husen, E.; Saraswati, R.; Setyorini, D.; De Neve, S. Soil microbial communities and activities under intensive organic and conventional vegetable farming in West Java, Indonesia. Appl. Soil Ecol. 2010, 45, 112-120. [CrossRef]

53. Lloyd, A.B.; Sheaffe, M.J. Urease activity in soils. Plant Soil 1973, 39, 71-80. [CrossRef]

54. Liu, J.G.; Zhang, W.; Yan-Bin, L.I.; Sun, Y.Y.; Bian, X.M. Effects of Long-Term Continuous Cropping System of Cotton on Soil Physical-Chemical Properties and Activities of Soil Enzyme in Oasis in Xinjiang. Sci. Agric. Sin. 2009, 42, 725-733.

55. Chen, H.; Yang, X.; Wang, H.; Sarkar, B.; Shaheen, S.M.; Gielen, G.; Bolan, N.; Guo, J.; Che, L.; Sun, H.; et al. Animal carcass- and wood-derived biochars improved nutrient bioavailability, enzyme activity, and plant growth in metal-phthalic acid ester co-contaminated soils: A trial for reclamation and improvement of degraded soils. J. Environ. Manag. 2020, 261, 110246. [CrossRef] [PubMed]

56. Liu, Y.; Dai, Q.; Jin, X.; Dong, X.; Peng, J.; Wu, M.; Liang, N.; Pan, B.; Xing, B. Negative Impacts of Biochars on Urease Activity: High pH, Heavy Metals, Polycyclic Aromatic Hydrocarbons, or Free Radicals? Environ. Sci. Technol. 2018, 52, 12740-12747. [CrossRef]

57. Huang, D.; Liu, L.; Zeng, G.; Xu, P.; Huang, C.; Deng, L.; Wang, R.; Wan, J. The effects of rice straw biochar on indigenous microbial community and enzymes activity in heavy metal-contaminated sediment. Chemosphere 2017, 174, 545-553. [CrossRef] [PubMed]

58. Wong, J.T.F.; Chen, X.; Deng, W.; Chai, Y.; Ng, C.W.W.; Wong, M.H. Effects of biochar on bacterial communities in a newly established landfill cover topsoil. J. Environ. Manag. 2019, 236, 667-673. [CrossRef] [PubMed]

59. Zhang, M.; Wang, J.; Bai, S.H.; Zhang, Y.; Teng, Y.; Xu, Z. Assisted phytoremediation of a co-contaminated soil with biochar amendment: Contaminant removals and bacterial community properties. Geoderma 2019, 348, 115-123. [CrossRef]

60. Steinbeiss, S.; Gleixner, G.; Antonietti, M. Effect of biochar amendment on soil carbon balance and soil microbial activity. Soil Biol. Biochem. 2009, 41, 1301-1310. [CrossRef]

61. Tang, J.; Zhang, L.; Zhang, J.; Ren, L.; Zhou, Y.; Zheng, Y.; Luo, L.; Yang, Y.; Huang, H.; Chen, A. Physicochemical features, metal availability and enzyme activity in heavy metal-polluted soil remediated by biochar and compost. Sci. Total Environ. 2020, 701, 134751. [CrossRef] 